\title{
Creating a Bigger Bath Using the Deferred Tax Valuation Allowance
}

\author{
THEODORE E. CHRISTENSEN* \\ GYUNG H. PAIK \\ EARL K. STICE \\ Brigham Young University
}

May 2007

\begin{abstract}
We appreciate helpful comments from the anonymous reviewer, Carol Yu, workshop participants at Brigham Young University, the 2006 AAA Annual meeting, and the 2003 AAA Western Regional Meeting. We also wish to express our appreciation to David Day, Jared Jensen, and Steve Stubben for their valuable research assistance.

*Address correspondence to: Ted Christensen, School of Accountancy, Marriott School of Management, 540 TNRB, Brigham Young University, Provo, Utah 84602-3100. Phone: (801) 422-1768, Email: ted_christensen@byu.edu.
\end{abstract}




\title{
Creating a Bigger Bath Using the Deferred Tax Valuation Allowance
}

\begin{abstract}
The provisions of SFAS No. 109 allow U.S. companies to make an earnings big bath even bigger through the establishment of a deferred tax valuation allowance. At the time a firm recognizes a non-cash charge, it also recognizes a deferred tax asset to represent the future tax benefits of the charge. Recognition of the deferred tax asset partially mitigates the negative earnings impact of the special charge. However, if the firm does not expect to have sufficient future taxable income to utilize the future tax benefits of the charge, SFAS No. 109 requires the firm to establish a deferred tax valuation allowance, effectively eliminating the recognized deferred tax asset. Thus, the establishment of the valuation allowance amplifies the negative earnings impact of the noncash charge. We use a valuation allowance prediction model to identify firms that create a largerthan-expected valuation allowance; these firms may be creating a large valuation allowance as a reserve to be used to manage earnings in a subsequent period. We find that the vast majority of these larger-than-expected valuation allowances apparently reflect informed management pessimism about the future in that these firms actually do have poorer operating performance in subsequent periods. Nonetheless, we also identify a specific set of firms that appear to have used a subsequent reduction in the valuation allowance to change a reported loss into a reported profit.
\end{abstract}

Keywords: deferred taxes; valuation allowance; big bath; earnings management 


\section{INTRODUCTION}

This paper examines whether firms making large write-offs or taking restructuring charges use the deferred tax valuation allowance to make an earnings big bath even bigger. The provisions of Statement of Financial Accounting Standard (SFAS) No. 109 require U.S. firms that take a non-cash charge to recognize a deferred tax asset to represent the future tax benefits of the charge. Recognition of the deferred tax asset partially mitigates the negative earnings impact of the special charge. However, if it is deemed more likely than not that the elements of the charge will not yield future tax benefits, a deferred tax valuation allowance is also established, effectively eliminating either all or part of the recognized deferred tax asset. ${ }^{1}$ As a result, with the recognition of a valuation allowance, the negative earnings impact of the non-cash charge is amplified. We investigate whether some big bath firms strategically create a deferred tax valuation allowance as a reserve to be used to manage earnings in a subsequent period.

Prior research suggests that earnings baths can be used as an extreme form of earnings management (Moehrle, 2002). Regulators argue that big bath firms simply accelerate future charges into the current period in order to artificially boost future earnings. For example, former SEC chairman Arthur Levitt criticized firms that take restructuring charges as part of a big bath. He stated that the decision to restructure "should not lead to flushing all the associated costsand maybe a little extra—through the financial statements." In addition to urging standard setters to clarify accounting rules, he vowed to increase SEC scrutiny of firms taking restructuring charges (Levitt, 1998). ${ }^{2}$

\footnotetext{
${ }^{1}$ According to the standards of the International Accounting Standards Board (IASB), found in IAS 12, a deferred tax asset is recognized to the extent that it is probable that part or all of the associated tax benefits will be utilizable. In April 2003, the IASB agreed that, in the context of accounting for deferred tax assets, "probable" means "more likely than not." IAS 12 does not require the establishment of a separate valuation allowance, but the required annual evaluation and adjustment of the carrying value of any deferred tax assets accomplishes the same end result. ${ }^{2}$ Since Mr. Levitt's speech, the FASB has limited the flexibility of companies to use a restructuring charge as part of a big bath. See SFAS No. 144 (on impairment losses) and SFAS No. 145 (on the timing of the recognition of restructuring obligations).
} 
Restructuring charges or write-offs are typically not tax deductible in the current period because, although accounting standards allow for the immediate recognition of expected decreases in the value of assets and the creation of future obligations, the tax code does not allow such deductions until the obligations are paid or the assets are disposed. Accordingly, SFAS No. 109 requires that these timing differences between book and taxable income be recognized as deferred tax assets in the period the non-cash charges are recognized. If firms estimate that they will not have sufficient taxable income in future years to recognize some or all of the future tax benefits associated with the special charge, they must establish a valuation allowance to offset the portion of the deferred tax asset that they deem to be unrealizable. Although SFAS No. 109 provisions are fairly explicit with respect to the recognition of deferred tax assets, firms have significant discretion in determining whether a deferred tax asset valuation allowance is necessary and, if so, what the amount should be. This discretion allows managers to make a big bath even bigger by recognizing a larger valuation allowance than they deem to be necessary. This larger-than-warranted valuation allowance may serve as a reserve that can be used to bolster income in future periods by changing the estimates and reversing the allowance. The valuation allowance is attractive in terms of earnings management because it is relatively easy to justify a change in estimates in future years in order to reverse the allowance. This is a prime example of the type of "cookie jar reserves" criticized by Arthur Levitt (1998).

We examine whether firms use the valuation allowance to make a big bath bigger. In order to do so, we identify a sample of firms that recognize large restructuring charges or writeoffs. Following Miller and Skinner (1998) and Behn et al. (1998), we estimate a valuation allowance prediction model in order to identify those firms that are most likely to have established (1) a larger-than-necessary valuation allowance to increase the magnitude of a big bath (bigger bath firms) or (2) a smaller-than-necessary valuation allowance to mitigate the impact of the special charge or write-off (smaller bath firms). Our results do not support the view 
that the primary factor behind the establishment of a deferred tax asset valuation allowance in a big bath setting is to create a cookie jar reserve. Instead, our results suggest that managers use private information about future operating performance to establish a valuation allowance that may be larger than expected (reflecting pessimism about the future) or smaller than expected (reflecting optimism about the future). Using operating performance data for subsequent periods, we demonstrate that this optimism or pessimism is justified.

Notwithstanding the fact that, on average, big bath firms appear to appropriately establish a deferred tax valuation allowance to reflect expectations about future performance, we also identify a small set of firms that apparently used a subsequent reduction in these valuation allowances to change a reported loss into a reported profit. The incidence of such cases is small, with this strategy being used by fewer than $10 \%$ of the firms that could have used it. This small number is not surprising given the transparent nature of this earnings management technique; for example, it can be easily detected by academic researchers using publicly-available data.

Our results contribute to the earnings management and big bath literatures in four ways. First, we show that firms can use the deferred tax valuation allowance as an additional element in a big bath. Second, we find evidence that, on average, firms do not use this highly visible technique as a routine earnings management tool. Third, we show that management's choice of the magnitude of a deferred tax valuation allowance established in connection with a big bath is informative about the future operating performance of the firm. Finally, we demonstrate that, even in a transparent setting, a few firms strategically manage accounting reserves to reach earnings targets.

The remainder of the paper is organized as follows. Section 2 develops our hypotheses. Section 3 describes our sample selection, methodology, and the characteristics of our sample firms. Section 4 presents the results, and section 5 provides concluding comments. 


\section{HYPOTHESIS DEVELOPMENT}

\section{(i) Earnings Management and the Deferred Tax Asset Valuation Allowance Account}

We examine whether U.S. firms strategically choose the level of the deferred tax asset valuation allowance recognized when they incur special charges (restructuring costs or writeoffs). The provisions of SFAS No. 109 allow firms substantial discretion in determining the level of the valuation allowance. Firms may use this flexibility either to make a big bath even bigger by recognizing a large valuation allowance or to mitigate the earnings impact of a special charge by recognizing a smaller-than-warranted valuation allowance. In addition, it is possible that firms may use this discretion to arbitrarily set the allowance account balance too high, thereby allowing the later reversal of these "cookie jar reserves" to manage earnings. Prior studies, in general, have found empirical evidence suggesting that firms set the level of the valuation allowance consistent with the provisions of SFAS No. 109 and have found little evidence of earnings manipulation. ${ }^{3}$

For example, Miller and Skinner (1998) find evidence suggesting that the empirical determinants of the valuation allowance for deferred tax assets are consistent with those variables described in SFAS No. 109. That is, the allowance is larger for firms with relatively more deferred tax assets and smaller for firms with higher levels of expected future taxable income. On the other hand, they find little evidence that managers use the valuation allowance to manage earnings. Because their sample is limited to firms that took relatively large Other PostEmployment Benefit (OPEB) charges when they adopted SFAS No. 106, they suggest that their sample firms may not be the most appropriate group to use in searching for earnings management involving the valuation allowance. Behn et al. (1998) also find empirical evidence

\footnotetext{
${ }^{3}$ Prior research has investigated various aspects of accounting for deferred tax assets and liabilities in different countries (e.g., Bauman and Das, 2004; Gaeremynck and Gucht, 2004; Citron, 2001; Arnold, 1994; Brown, et al., 1987; Wolk and Tearney, 1980; and Findlay and Williams, 1981). We do not attempt to provide a complete review of research on accounting for deferred taxes, but instead focus on the flexibility of managers in the United States in accounting for the deferred tax asset valuation allowance.
} 
that variables listed as examples in SFAS No. 109 are highly associated with cross-sectional differences in the level of the valuation allowance. However, they do not examine the question of whether companies use the valuation allowance to manage earnings.

Kumar and Visvanathan (2003) perform an event study to examine investors' response to press releases made by firms making valuation allowance changes. Their evidence suggests that disclosures of changes in the deferred tax valuation allowance provide information beyond contemporaneous earnings reports. They argue that, similar to discretionary accruals, the valuation allowance can inform investors about future profitability. They also examine whether stock returns are associated with the opportunistic use of the valuation allowance to manage earnings. However, their results do not indicate an association between security price movements and earnings management via the valuation allowance.

Phillips et al. (2003) find that the deferred tax expense, their empirical surrogate for book-tax differences, is generally incrementally informative relative to total accruals and abnormal accruals derived from two "Jones-type" models in detecting earnings management to avoid an earnings decline (e.g., Jones 1991; Dechow et al. 1995). In a follow-up study, Phillips et al. (2004) decompose the total change in net deferred tax liabilities into eight components (including the valuation allowance account) to determine which types of accounts are associated with earnings management activities. They find that firms set their valuation allowance accounts consistent with guidance in SFAS No. 109. Thus, they find no evidence that managers use the valuation allowance account to manage earnings to avoid an earnings decline.

Schrand and Wong (2003) find evidence that most banks do not recognize a valuation allowance in order to manage earnings, but rather to follow the guidelines of SFAS No. 109. Similarly, Bauman et al. (2001) utilize a sample of Fortune 500 firms to examine earnings management via changes in the deferred tax asset valuation allowance. Their cross-sectional tests find virtually no evidence in support of earnings management. Although critics of SFAS No. 109 
argue that the valuation allowance account can be used in "big bath" behavior, Bauman et al. find empirical evidence suggesting that arguments about firms using the valuation allowance in "big bath" behavior may be exaggerated. They suggest a contextual approach that can identify specific instances in which earnings management may exist. Consistent with this recommendation, we examine a particular setting in which firms are more likely to use the valuation allowance account to increase the magnitude of a big bath or to mitigate the negative effects of a special charge or write-off.

Two prior studies find evidence of earnings management using the valuation allowance. Burgstahler et al. (2002) investigate earnings management related to deferred tax assets and argue that the deferred tax asset context is one in which incentives to manage earnings are particularly strong. They use the Burgstahler and Dichev (1997) methodology to compare firmyears with small scaled profits to firm-years with small scaled losses under the assumption that ex post there is a higher probability that firms with small scaled profits engaged in earnings management. They find evidence that firms with changes in the net deferred tax asset account that convert a loss to a profit decrease the relative valuation allowance by a larger amount than firms where changes in deferred tax assets do not convert a loss to a profit. Frank and Rego (2005) examine whether managers use the valuation allowance account to mange earnings around certain earnings targets. They find substantial evidence that firms use the valuation allowance account to manage earnings toward the mean analyst forecast. However, they do not find evidence that firms use the valuation allowance account to manage earnings around the positive net income and prior years' reported earnings targets. Thus, these studies find evidence that firms use the valuation allowance to meet earnings targets. We further this research by investigating the use of the valuation allowance to establish a "cookie jar reserve" at the time of an earnings bath. 


\section{(ii) Earnings Management and Large One-time Charges}

Francis et al. (1996) investigate a sample of firms making write-offs between 1989 and 1992, including some described as restructuring charges. They find factors associated with both earnings manipulation and asset impairment to be important determinants in write-off decisions. Moehrle (2002) finds evidence that some firms reverse a portion of restructuring charges in a later quarter to beat analysts' forecasts and to avoid reporting net losses. He also finds some evidence that firms record reversals to avoid earnings declines. Overall, his results are consistent with firms using restructuring accrual reversals to manage earnings.

\section{(iii) Hypotheses}

We examine a powerful setting for detecting earnings management associated with the deferred tax valuation allowance. Our sample is comprised of firms that take large restructuring charges or write-offs. As mentioned previously, the recognition of a deferred tax asset valuation allowance increases the magnitude of a big bath. A valuation allowance might be recognized because concern about future profitability calls into question the realizability of the deferred tax asset. According to the provisions of SFAS No. 109, if it is "more likely than not" that the deferred tax benefits will not be realized, a valuation allowance must be recognized.

Alternatively, a larger-than-necessary valuation allowance might be recognized in order to establish a "cookie jar reserve" that can be reversed in future periods or a smaller-than-necessary valuation allowance might be recognized to minimize the earnings impact of a special charge or write-off. We attempt to distinguish between these two motivations in recognizing a deferred tax valuation allowance by comparing the magnitude of the actual recognized allowance to the predicted magnitude derived from a model based on relevant firm characteristics identified by SFAS No. 109 and prior research (such as past profitability and the existence of offsetting deferred tax liabilities). We designate firms that recognize an unexpectedly large deferred tax valuation allowance as "bigger bath firms." If there are firms that use deferred tax accounting to 
create a reserve that can be reversed to bolster earnings in a subsequent year, then it is more likely that they are the "bigger bath firms" because they have established a larger-than-expected valuation allowance. Therefore, we explore whether bigger bath firms are more likely than smaller bath firms to decrease their valuation allowance in subsequent years.

\section{$H_{1 A}$ : Bigger bath firms are more likely to subsequently decrease the deferred tax asset valuation allowance in the year following the bath than are smaller bath firms.}

A competing hypothesis is that managers use their private information about the future prospects of their company to appropriately establish the deferred tax valuation allowance. If managers are in possession of private information that causes them to be more pessimistic about the company's future than would be an outsider using publicly-available data, then they will establish a higher-than-expected allowance. In our formulation, the proxy for the view of an outsider is the output from the valuation allowance prediction model which uses publiclyavailable data. On the other hand, if managers possess optimistic private information, they will establish a lower-than-expected allowance. Our proxy for managers' private information during the big bath year about future performance is actual operating performance in the year after the big bath. This hypothesis is stated as follows.

\section{$H_{1 \mathrm{~B}}$ : Bigger bath firms have worse operating performance in Year +1 (relative to the bath year) compared to smaller bath firms.}

Once a deferred tax valuation allowance is established, whatever the motivation, it becomes a tempting tool for earnings management. To reduce or eliminate the allowance, and

thus boost earnings on a dollar-for-dollar basis, a manager need only argue that it is now "more likely than not" that future earnings will in fact be sufficient to allow for the realization of the deferred tax asset. A manager would feel great incentive to try to make that argument if, for example, doing so would convert a bottom-line loss into a profit. However, unlike many other accrual decisions that can be used to manage reported earnings, the impact of a valuation 
allowance accrual decision is very transparent; the beginning and ending balances of the valuation allowance, and the precise dollar earnings impact of any change, are clearly given in the notes to the financial statements. In contrast, the effects of revenue recognition or operating expense accrual decisions made for earnings management purposes are difficult, if not impossible, for an outsider to unravel.

The large valuation allowances associated with big bath firms provide a window into the dark world of earnings management. If managers blatantly manage earnings, then a large fraction of the firms that can use a reduction in their valuation allowance to change a loss into a profit will do so. On the other hand, if the transparency associated with this form of earnings management creates some caution among managers and their auditors, then the number of firms that seemingly take advantage of the valuation allowance to turn a loss into a profit will be relatively small. We have no prediction about whether the number of blatant earnings managers will be large or small; we will report our results in the spirit of an exploratory analysis.

\section{SAMPLE SELECTION, METHODOLOGY, AND DESCRIPTIVE EVIDENCE}

\section{(i) Sample Selection Process}

The sample selection process consists of three stages. First, we identify all companies on the annual Compustat file that report large negative special items (Compustat annual data item \#17) during the years 1996 through $1998 .{ }^{4}$ Specifically, we include companies that reported

\footnotetext{
${ }^{4}$ We include firms from the Compustat Research file in addition to the Primary, Supplementary, and Tertiary Annual files to mitigate any potential selection bias. The sample period begins immediately after the first effective dates of two major accounting rules regarding special charges. EITF 94-3 became effective in 1994 and SFAS No. 121 became effective in 1995.
} 
special charges exceeding ten percent of their total assets during these years. ${ }^{5}$ This process yields an initial set of 1,271 potential sample firms traded on the major U.S. stock markets (NYSE, AMEX, and NASDAQ).

In order to identify firms that are likely to exhibit "big bath" behavior, we then search the public earnings press releases of these 1,271 firms for evidence of large write-offs and/or restructuring charges. In order to do this, we search the LexisNexis database to identify sample firms' earnings announcements. Specifically, we explore the "Company/Allnews (Arcnews)" file in LexisNexis, which contains press releases of publicly traded firms. Our search includes terms such as "restructuring," "write-off," "write-down," and other variant forms of these expressions. This process identifies 567 firms with large write-offs and/or restructuring charges from 1996 to 1998.

Third, we search SEC 10-K filings in the EDGAR database to obtain deferred tax and valuation allowance data for this sample of firms reporting large write-offs or restructuring charges. In order to complete our initial analysis, we require deferred tax data for the year preceding and the year of the restructuring charge or large write-off. This search of the EDGAR database yields 522 potential sample firms. Then we required our sample firms file their future two years of data with the SEC. Our final sample consists of 444 large restructuring charge/write-off announcement firms with reported valuation allowance data.

Finally, in order to verify that any movements in deferred tax-related account balances are not an artifact of industry or market wide effects, we identify a set of control firms that did not incur large write-offs or special items during these years. Therefore, we identify a group of control firms matched on industry and size. Specifically, we match each sample firm to the

\footnotetext{
${ }^{5}$ Francis et al. (1996) use a one percent cutoff in selecting their sample. However, we employ a stricter requirement (ten percent) in order to identify potential "big bath" special charges. In addition, the use of this cutoff ensures a reasonable sample size for the hand collection of deferred tax data from the annual Form 10-K filings of sample firms.
} 
Compustat firm closest in size (based on total assets) in the same four-digit SIC classification; we require the control firms to report special charges close to zero. None of our control firms reports special charges that exceed $1 \%$ of total assets. We perform this matching process during the year of each sample firm's special charge to avoid the effects of potential differences in macroeconomic conditions on control firms' deferred tax accounts. This process yields a final sample of 444 "bath" firms and 444 control firms.

(ii) Methodology

In order to distinguish between bigger bath and smaller bath firms, we regress the deferred tax asset valuation account as a percentage of deferred tax assets (ALLOWDTA) on variables which prior studies have found to be determinants of the deferred tax valuation allowance. We note at the outset that our intent in this study is to investigate whether managers use the valuation allowance opportunistically. Our objective is not to develop the best valuation allowance prediction model. We simply employ all significant variables identified by Miller and Skinner (1998), hereafter MS, and Behn, Eaton, and Williams (1998), hereafter BEW, in the following regression model ${ }^{6}$ :

$$
\begin{array}{cl}
\text { ALLOWDTA }=a_{0}+a_{1} \text { FUTURE }+a_{2} \text { EARN }+a_{3} \text { MKTBOOK }+a_{4} \text { DISTRESS }+ \\
\text { Where: } a_{5} \text { STRATEGY }+a_{6} \text { CONTIN }+a_{7} \text { PASTROA }+a_{8} Z-S C O R E+\varepsilon
\end{array}
$$

\footnotetext{
${ }^{6}$ We use the same names and variable definitions reported by MS and BEW.
} 


$\begin{array}{lll}\text { MKTBOOK }= & \begin{array}{l}\text { Market value of common equity divided by book } \\ \text { value of common equity (following BEW), }\end{array} \\ \text { DISTRESS } & = & \begin{array}{l}\text { Indicator variable that is one if operating cash flow, } \\ \text { operating income, or earnings are negative } \\ \text { (following BEW) }\end{array} \\ \text { STRATEGY } & = & \begin{array}{l}\text { Federal income tax expense divided by net } \\ \text { operating income (following BEW), }\end{array} \\ \text { Indicator variable coded one if the firm has a } \\ \text { material contingency and zero otherwise (following } \\ \text { BEW), } \\ \text { PASTROA }\end{array}$

We use pooled data for both control and sample firms in year $\mathrm{t}-1$ (where year $\mathrm{t}$ is the year of the write-off or restructuring charge) and for the control group in year $\mathrm{t}$ in order to estimate the parameters of the regression model. We then use the parameter estimates to calculate a predicted valuation allowance as a percentage of deferred tax assets (ALLOWDTA) for sample firms in year t. Finally, we use the prediction error (actual ALLOWDTA minus predicted ALLOWDTA) to distinguish between bigger and smaller bath firms.

(iii) Descriptive Evidence about Sample and Control Firms

Table 1 contains descriptive statistics for sample and control firms. Panel A indicates a wide distribution across industries among sample and control firms with the largest concentration of firms, 50\%, in the manufacturing industries (SIC codes 2000-3999) and in the service industries, 30\% (SIC codes 7000-8999).

Panel B compares sample and control firms based on size and other variables used in subsequent analyses. Panel B also reports comparisons of other variables, drawn from BEW

\footnotetext{
${ }^{7}$ Although the published version of Shumway's (2001) results differ slightly from those reported in his 1997 working paper, we use the coefficients from his working paper to maintain comparability to Miller and Skinner (1998).
} 
(1998) and MS (1998), which we use to generate a firm-specific prediction of the level of the deferred tax asset valuation allowance. The Panel B profile results indicate that sample firms have significantly (1) lower deferred tax liabilities, FUTURE, (2) higher average operating earnings over the most recent three years, EARN, (3) higher probability of financial distress, DISTRESS, (4) lower federal taxes as a percentage of net operating income, STRATEGY, (5) lower average return on assets over the previous three years, PASTROA, and (6) higher probability of bankruptcy, Z-SCORE. ${ }^{8}$ Taken together, these descriptive statistics suggest that relative to firms of similar size in similar industries, sample firms generally face significantly more difficult financial prospects than do their competitors.

Table 2 presents detailed descriptive statistics for all deferred tax accounts (scaled by total assets) as reported in the tax footnote of the 10-K filings for the sample firms (Panel A) and the control firms (Panel B). A comparison of Panels A and B suggests that sample and control firms have similar levels of deferred tax assets, DTA, during the two years prior to the write-off or restructuring charge year with a median deferred tax asset balance between five and eight percent of total assets for both sets of firms. In contrast, the median balance in the deferred tax asset account of the sample firms more than doubles in the year of the special charge to $15.8 \%$ of total assets whereas the deferred tax asset balance for the control firms remains basically unchanged. ${ }^{9}$ The median balance in the deferred tax asset valuation allowance account, VALALLOW, of sample firms is between one and two percent of total assets in the two years preceding the special charge year; for the control firms, the valuation allowance balance is much less than one percent. This difference reflects the general financial uncertainty surrounding the sample firms - the same conditions that led to the special charge in year $\mathrm{t}$ also led to more doubt about the realizability of deferred tax assets, and thus a higher valuation allowance, in years t-2

\footnotetext{
${ }^{8}$ Note that a higher (lower) Z-score indicates a lower (higher) probability of bankruptcy.

${ }^{9}$ In order to provide meaningful comparisons of sample and control firms, we report results after winsorizing the data at the $1 \%$ and $99 \%$ levels of each variable's distribution.
} 
and $t-1$. In the special charge year, the median balance in the valuation allowance account of sample firms increases dramatically (to $9.1 \%$ of total assets) while the median balance for the control firms is actually lower than in the preceding two years. For comparison, the median balance in the deferred tax liability account, DTL, remains relatively constant at about one percent of total assets for each of the three years reported for both sample and control firms.

\section{RESULTS OF HYPOTHESIS TESTS}

\section{(i) Changes in the Deferred Tax-Related Balances for Sample and Control Firms}

Because of the recognition of a large special charge, we expect sample firms to increase their deferred tax asset valuation allowance relative to their deferred tax asset account in the special charge year relative to firms of similar size in the same industry that did not recognize a special charge. Table 3 reports comparisons of sample firms and control firms matched on both firm size and four-digit SIC code. Panel A indicates a mean increase of approximately $3 \%$ in sample firms' valuation allowance as a percentage of the deferred tax assets, $\triangle$ ALLOWDTA, in the year preceding the special charge year. This suggests that at least one year prior to the writeoff or restructuring charge, some sample firms anticipate future financial difficulty that will make it more likely than not that they cannot utilize all of the tax benefits associated with their deferred tax assets. Moreover, sample firms increase their valuation allowance account as a percentage of deferred tax assets, on average, by approximately $11 \%$ in the special charge year.

The $t$-statistic indicates that this increase is significant at the 0.01 level. On the other hand, Panel B reports that control firms decrease their valuation allowance (though the change is not significant) as a percentage of deferred tax assets in the year prior to the measurement year. Moreover, they continue to decrease their valuation allowance account in the measurement year and the decrease is statistically significant. 
In summary, the data presented in Table 3 confirm that, after controlling for industry and economy wide effects, the deferred tax asset and associated valuation allowance account balances increased in the special charge year for the sample firms. This is not surprising - the deferred tax asset balance should increase because special charges are typically composed of items, such as asset writedowns and restructuring obligation accruals, that are not tax deductible until they are realized, which is usually several years later. The valuation allowance should also increase, both in absolute terms and as a percentage of the amount of deferred tax assets, because the existence of the special charge indicates unsettled financial conditions. These unsettled financial conditions increase the likelihood that it will be determined that it is more likely than not that portions of the deferred tax asset will never be realized. In the next section we explore whether the level of the deferred tax asset valuation allowance is chosen strategically and whether a reversal of the allowance in the subsequent year is predictable.

\section{(ii) Distinguishing between bigger bath and smaller bath firms}

In order to distinguish between firms that exhibit bigger bath and smaller bath behavior, we use firm characteristics to generate a predicted level for the deferred tax asset valuation allowance. Table 4 reports results for regression model 1; the parameters from this model are used to generate the predicted allowance amount. This model regresses the valuation allowance as a percentage of deferred tax assets, ALLOWDTA, on factors that prior research has found to be significantly associated with the level of the valuation allowance account (see MS, 1998 and BEW 1998). In order to estimate model 1, we include data for both sample and control firms in the year prior to the special charge year and for control firms in the special charge year. Table 4 indicates that almost all of the predictor variables are highly significant $(p<0.01)$ in directions consistent with what is found in prior research. The two exceptions are for market-to-book ratio of common equity, MKTBOOK, and an indicator coded one if the firm reports a material contingency in their footnote disclosures, CONTIN. The model's adjusted- $\mathrm{R}^{2}$ of 0.4508 is 
generally consistent with OLS adjusted-R ${ }^{2}$ values reported by MS (1998), 0.417, and BEW (1998), 0.462.

We use the parameter estimates from the Table 4 regression to calculate a predicted valuation allowance as a percentage of deferred tax assets for sample firms in the special charge year. We then calculate a valuation allowance prediction error by subtracting the predicted value from each firm's actual valuation allowance as a percentage of deferred tax assets, ALLOWDTA. We define bigger bath firms as those in the top $33 \%$ of the valuation allowance prediction error distribution (i.e. firms whose actual ALLOWDTA is the highest relative to their predicted ALLOWDTA). We define smaller bath firms as those in the bottom $33 \%$ of the valuation allowance prediction error distribution (i.e. firms whose actual ALLOWDTA is the lowest relative to their predicted ALLOWDTA).

(iii) Are bigger bath firms more likely to subsequently decrease the deferred tax asset valuation allowance in the year following the bath than are smaller bath firms. $\left(H_{1 A}\right)$ ?

Hypothesis $\mathrm{H}_{1 \mathrm{~A}}$ examines whether bigger bath firms appear to use the valuation allowance in the bath year in order to establish a "cookie jar reserve" that they use in the subsequent year to boost earnings. Table 5 reports comparisons of changes in the valuation allowance in the year subsequent to the special charge year for firms that we designate, ex ante, as bigger bath and smaller bath firms. Panel A indicates that bigger bath firms decrease the valuation allowance as a percentage of deferred tax assets ( $\triangle$ ALLOWDTA), on average, in the year subsequent to the special charge and the decrease is statistically significant. Panel B reports that smaller bath firms continue to increase the valuation allowance significantly as a percentage of deferred tax assets in the year following the special charge. Finally, Panel $\mathrm{C}$ shows that the change in the valuation allowance is significantly lower (more negative) for bigger bath firms than for smaller bath firms. 
The results in Table 5 point toward a conclusion that the bigger bath firms intentionally overstate their valuation allowance in Year 0 in order to reverse the allowance (and increase earnings) in Year +1 . However, there are several cautions that suggest that such a conclusion is premature. First, a deferred tax valuation allowance reduction increases earnings only if there is an actual reduction in the dollar amount of the allowance. A change in the percentage relationship between the valuation allowance and the deferred tax asset balance does not definitely indicate either an increase or a decrease in the actual dollar amount of the valuation allowance. Accordingly, the results in Table 5 showing a significant difference in the allowance amount as a percentage of the deferred tax asset balance do not directly address the impact of such a change on earnings in Year +1 . Second, because the big bath and small bath firms are identified using error terms from a prediction model, the apparent reversal exhibited by the big bath firms could merely be a statistical artifact that is nothing more than reversion to the mean.

A final factor that clouds the interpretation of the results in Table 5 is that, upon closer inspection, a large number of the sample firms do not appear to have exercised any discretion in the establishment of their valuation allowance amounts. These firms fall into two groups. One group of firms did not establish any valuation allowance. These firms will hereafter be called the ZERO firms. The ZERO firms, as a group, have greater financial strength than the other sample firms. For the most part, the ZERO firms had never established a valuation allowance before the sample year and continued that pattern in spite of the financial uncertainty suggested by the large special charge in the sample year. These firms apparently had no significant doubt about their ability to generate sufficient future income to be able to completely realize their deferred tax assets.

A second group of firms that did not appear to exercise discretion in selecting their valuation allowance amount actually established the maximum possible valuation allowance. For these firms, the valuation allowance was either equal to the deferred tax asset balance or was 
equal to the difference between the deferred tax assets and the deferred tax liabilities. In both cases, the valuation allowance was set such that the net reported deferred tax asset (deferred tax asset less valuation allowance less deferred tax liability) was zero; establishing a higher valuation allowance was not possible. We designate these as the MAX firms. As one might expect (and as demonstrated later in the paper), these MAX firms were significantly weaker financially than the other sample firms. Accordingly, the accounting rules were quite clear in requiring that these firms establish the maximum possible valuation allowance.

Because our objective is to focus on the strategy surrounding the establishment of a deferred tax valuation allowance, it makes sense to treat the ZERO and MAX firms separately and apply the prediction model only to the remaining firms. Also, because valuation allowance reversals impact earnings only to the extent that they represent an actual change in dollar amount, we can enhance our understanding of what the sample firms are doing by focusing on this view of a reversal.

In Table 6, the sample firms with available deferred tax data in Year +1 or Year +2 are categorized into four groups: the ZERO and MAX groups described earlier as well as a set of SMALL firms (the valuation allowance is smaller than expected given the prediction model discussed earlier) and a set of LARGE firms. For each group, firms that reduced their valuation allowance balance in either Year +1 or Year +2 are designated as reversal firms. As seen in Table 6, the frequency of valuation allowance reversals for the sample firms in the SMALL and LARGE groups is essentially the same (the small difference is statistically insignificant). These results suggest that the impression given by the Table 5 results is not correct; there is no evidence that, on average, bath firms establish larger-than-necessary valuation allowances in Year 0 in order to reverse those allowances and increase earnings in Year +1 or Year +2 . (iv) Do bigger bath firms have worse operating performance in Year +1 (relative to the bath year) compared to smaller bath firms. $\left(H_{1 B}\right)$ ? 
There may not be evidence of widespread creation of cookie jar reserves by bath firms using the deferred tax valuation allowance in a bath year, but the determination of these allowance balances is still an interesting object of study. In fact, as shown in Table 7, and as suggested in Hypothesis $\mathrm{H}_{1 \mathrm{~B}}$, the magnitude of a valuation allowance established in Year 0 provides information about how the firm will perform in Year +1 . In Panel A, it can be seen that operating performance in Year +1 , measured by either earnings before interest, taxes, depreciation, and amortization (EBITDA) or operating income, decreases monotonically with increasing levels of the valuation allowance established in Year 0 . The median value of operating income divided by total assets in Year +1 is $-11.5 \%$ for the MAX firms compared to $+7.7 \%$ for the ZERO firms. The differences shown in Panel A are consistent with managers using their private information in Year 0 about their firm's future to appropriately determine the deferred tax valuation allowance amount in Year 0.

The results in Table 7, Panel B demonstrate that the valuation allowance reversals that occur in Year +1 and Year +2 are, on average, related to operating results that occur after the initial valuation allowance balance was established in Year 0. For each of the four valuation allowance groups, the firms that reversed their valuation allowance had significantly better operating performance in Year +1 than did the firms that did not reverse. A reasonable interpretation of these results is that the primary driving factor behind the reversals was improved operating performance and not manipulation of the allowance balances for the purposes of earnings management.

The results reported in the preceding tables are on-average results. Although most firms appear to be appropriately applying the provisions of SFAS No. 109 in determining their deferrd tax valuation allowance balance in the year of a big bath, there still may be some subset of firms that uses the flexibility of the standards to create a valuation allowance cookie jar reserve. A search for such firms is summarized in Table 8. Reported earnings numbers and valuation 
allowance balances for Year +1 and Year +2 are used to identify those sample firms that could have reversed their valuation allowance in order to change a loss into a profit. The available data make it possible to identify 168 such opportunities, as shown in Table 8, Panel A. In each of these opportunities, the firm's net income before extraordinary items, before considering any

change it is valuation allowance, was negative. At the same time, the beginning balance in the firm's valuation allowance was large enough such that if the entire balance were reversed the earnings would have become positive. Prior research has shown that managers display a great interest in managing earnings to avoid reporting a loss. Hence, these opportunities are a likely place to observe the use of a valuation allowance reversal to manage earnings, if such uses occur. As shown in Panel A, managers of the sample firms took advantage of only 12 of the 168 opportunities to convert a loss into a profit using reversal of a deferred tax valuation allowance. The earnings and valuation allowance data for these 12 sample firms are listed in Panel B of Table 8. This small number of apparent earnings managers suggests that the transparency associated with this form of earnings management creates some caution among managers and their auditors.

\section{CONCLUSION}

This study examines the extent to which firms use the deferred tax valuation allowance to make a big bath even bigger. We use a valuation allowance prediction model to identify those firms that are most likely to have recognized an unexpectedly large valuation allowance as part of a big bath strategy. We find that the vast majority of these larger-than-expected valuation allowances apparently reflect informed management pessimism about the future in that these firms actually do have poorer operating performance in subsequent periods. We also find that subsequent reversal of valuation allowances established in a big bath year is associated with 
positive operating performance, suggesting that the reversal is driven by correct application of the accounting standards rather than by earnings management. Nonetheless, we also identify a small set of firms that appear to have used a subsequent reduction in the valuation allowance to change a reported loss into a reported profit indicating that although use of valuation allowance reversals as an earnings management tool may not be rampant, it still does exist.

The results in this paper may offer some useful insight in the current debate about whether accounting standards should be principles based. In some sense, the standard for determining whether a firm should establish a deferred tax valuation allowance is a principlesbased standard (although SFAS No. 109 does provide substantial implementation guidance). An argument against principles-based standards is that they are too susceptible to strategic manipulation. Our results strongly suggest that, perhaps because of the transparent disclosure associated with a deferred tax valuation allowance, managers are reluctant to use this judgmentbased accounting accrual to manage earnings. 


\section{REFERENCES}

Altman, E. (1968). "Financial Ratios, Discriminant Analysis and the Prediction of Corporate Bankruptcy." The Journal of Finance: 589-609.

Arnold, A. J. (1994). "The Adoption of Partial Deferral in the UK, 1977-1978: Evidence on the Accounting Choice." Journal of Business Finance \& Accounting 21 (Sept): 875888.

Bauman, C., M. Bauman, and R. Halsey. (2001). "Do Firms Use the Deferred Tax Asset Valuation Allowance to Manage Earnings?" The Journal of the American Taxation Association 23 (Supplement): 27-48.

Bauman, C., and S. Das. (2004). "Stock Market Valuation of Deferred Tax Assets: Evidence from Internet Firms." Journal of Business Finance \& Accounting 31 (Nov/Dec): 1223-1260.

Behn, B. K., T. V. Eaton, and J. R. Williams. (1998). "The Determinants of the Deferred Tax Allowance Account Under SFAS No. 109." Accounting Horizons 12: 63-78.

Brown, S. and J. Lippett. (1987). “Are Deferred Taxes Discountable?” Journal of Business Finance \& Accounting 14 (Spring): 121-141.

Burgstahler D., and I. D. Dichev. (1997). "Earnings, Adaptation and Equity value.” The Accounting Review 72: 187-215.

Burgstahler D., W.B. Elliott, and M. Hanlon. (2002). "How Firms Avoid Losses: Evidence of Use of the Net Deferred Tax Asset Account." Working Paper, University of Washington.

Citron, D. B. (2001). "The Valuation of Deferred Taxation: Evidence from the UK partial provision approach.” Journal of Business Finance \& Accounting 28 (Sept/Oct): 821-852.

Dechow, P., R. Sloan, and A. Sweeney. (1995). “Detecting Earnings Management.” The Accounting Review 70 No. 2: 193-225.

Financial Accounting Standards Board (FASB). 1992. Accounting for Income Taxes. Statement of Financial Accounting Standards No. 109. Norwalk, CT: FASB.

Findlay, M. C. and Williams, E. E. (1981). "Discounting Deferred Tax Liabilities: A Reply." Journal of Business Finance \& Accounting 8 (Winter): 593-597.

Francis, J., J. Hanna, and L. Vincent. (1996). "Causes and Effects of Discretionary Asset Write-Offs.” Journal of Accounting Research 34 (Supplement): 117-134.

Frank. M., and S.O. Rego. (2005). "Do Managers Use the Valuation Allowance Account to Manage Earnings around Certain Earnings Target?" Working Paper, University of Virginia. 
Gaeremynck, A. and L. V. D. Gucht. (2004). "The Recognition and Timing of Deferred Tax Liabilities.” Journal of Business Finance \& Accounting 31 (Sept/Oct): 985-1014.

Jones, J. (1991). "Earnings Management during Import Relief Investigations." Journal of Accounting Research 29: 193-228.

Kumar, K., and G. Visvanathan. (2003). "The Information Content of the Deferred Tax Valuation Allowance.” The Accounting Review 78 No 2: 471-490.

Levitt, A. (1998). "The Numbers Game.” Speech delivered at the New York University Center for Law and Business, September 28, 1998.

Miller, G., and D. Skinner. (1998). "Determinants of the Valuation Allowance for Deferred Tax Assets under SFAS No. 109.” The Accounting Review 73: 213-233.

Moehrle, S. 2002. Do Firms Use Restructuring Charge Reversals to Meet Earnings Targets? The Accounting Review 77: 397-414.

Phillips, J., Pincus, M., and S. O. Rego. (2003). "Earnings Management: New Evidence Based on Deferred Tax Expense." The Accounting Review 78: 491-521.

Phillips J., Pincus M., S. O. Rego, and H. Wan. (2004). "Decomposing Changes in Deferred Tax Assets and Liabilities to Isolate Earnings Management Activities." Journal of the American Taxation Association 26: 43-66.

Schrand, C., and M. H. F. Wong. (2003). "Earnings Management Using the Valuation Allowance for Deferred Tax Assets Under SFAS 109." Contemporary Accounting Research 20 No. 3: 579-611.

Shumway, T. (2001). "Forecasting Bankruptcy More Accurately: A Simple Hazard Model." Journal of Business 74: 101-124.

Wolk, H. I. and M. G. Tearney. (1980). "Discounting Deferred Tax Liabilities: Review and Analysis.” Journal of Business Finance \& Accounting 7 (Spring): 119-139. 
Table 1

Descriptive statistics for sample and control firms

\begin{tabular}{|c|c|c|c|c|c|c|c|c|c|}
\hline \multicolumn{10}{|c|}{ Panel A: Industry classification } \\
\hline \multirow[b]{2}{*}{ Group } & \multirow[b]{2}{*}{ Total } & \multicolumn{8}{|c|}{ SIC Code } \\
\hline & & $0-1999$ & $2000-2999$ & $3000-3999$ & $4000-4999$ & $5000-5999$ & $6000-6999$ & $7000-7999$ & $8000-8999$ \\
\hline Sample Firms & 444 & 7 & 55 & 164 & 16 & 54 & $\overline{9}$ & 110 & 29 \\
\hline Control Firms & 444 & 7 & 55 & 164 & 16 & 54 & 9 & 110 & 29 \\
\hline Total & 888 & 14 & 110 & 328 & 32 & 108 & 18 & 220 & 58 \\
\hline \multicolumn{10}{|c|}{ Panel B: Comparison of sample and control firms } \\
\hline \multirow{2}{*}{\multicolumn{2}{|c|}{ Variable }} & \multicolumn{3}{|c|}{ Sample Firms } & \multicolumn{3}{|c|}{ Control Firms } & \multicolumn{2}{|r|}{ Wilcoxon } \\
\hline & & $\mathrm{N}$ & Mean & Median & $\mathrm{N}$ & Mean & Median & $t$-statistic & Z-score \\
\hline TOTASSET & & 444 & 314.262 & 70.520 & 444 & 298.303 & 69.678 & 0.36 & 0.04 \\
\hline NETSALES & & 444 & 375.440 & 76.590 & 444 & 364.324 & 67.145 & 0.21 & 1.07 \\
\hline ALLOWDTA & & 444 & 0.559 & 0.671 & 444 & 0.351 & 0.038 & $7.37 * * *$ & $7.44 * * *$ \\
\hline FUTURE & & 444 & 0.262 & 0.069 & 444 & 0.793 & 0.169 & $-7.26 * * *$ & $-5.02 * * *$ \\
\hline EARN & & 444 & -0.084 & 0.013 & 444 & -0.011 & 0.059 & $-3.73 * * *$ & $-5.99 * * *$ \\
\hline МКТВООК & & 443 & 2.876 & 0.817 & 444 & 5.630 & 2.345 & $-5.14 * * *$ & $-8.52 * * *$ \\
\hline DISTRESS & & 444 & 0.946 & 1.000 & 444 & 0.414 & 0.000 & $20.64 * * *$ & $16.97^{* * *}$ \\
\hline STRATEGY & & 444 & 0.009 & 0.000 & 444 & 0.220 & 0.281 & $-3.02 * * *$ & $-9.13^{* * *}$ \\
\hline CONTIN & & 444 & 0.047 & 0.000 & 444 & 0.043 & 0.000 & 0.32 & 0.32 \\
\hline PASTROA & & 444 & -0.027 & 0.037 & 401 & 0.025 & 0.088 & $-2.17 * *$ & $-3.31 * * *$ \\
\hline Z-SCORE & & 444 & 0.291 & 1.845 & 444 & 4.541 & 5.151 & $-11.76 * * *$ & $-14.15^{* * * *}$ \\
\hline \multicolumn{10}{|c|}{ *** Indicates statistical significance at the 0.05 level (two-tailed test). } \\
\hline \multicolumn{10}{|c|}{ *** Indicates statistical significance at the 0.01 level (two-tailed test). } \\
\hline SIC Codes 1-1999 & \multicolumn{9}{|c|}{$=$ Mineral and Construction Industries. } \\
\hline SIC Codes 2000-2999 & \multicolumn{9}{|c|}{ = Manufacturing: Food, Tobacco, Textile, Lumber, Furniture, Paper, Printing, Chemicals, and Petroleum. } \\
\hline SIC Codes 3000-3999 & \multicolumn{9}{|c|}{ = Manufacturing: Rubber, Leather, Stone, Metal, Machinery, Electronic Equipment, Transportation Equipment, etc. } \\
\hline SIC Codes 4000-4999 & \multicolumn{9}{|c|}{$=$ Transportation, Communications, and Utilities. } \\
\hline SIC Codes 5000-5999 & \multicolumn{9}{|c|}{ = Wholesale trade (durable and non-durable) and Retail trade (building materials, general merchandise, food, automotive, apparel, home furnishings, dining, etc.). } \\
\hline SIC Codes 6000-6999 & \multicolumn{9}{|c|}{ = Financial services, insurance, and real estate industries. } \\
\hline SIC Codes 7000-7999 & \multicolumn{9}{|c|}{ = Service industries: hotels, personal services, business services, automotive repair, motion pictures, amusement and recreation services. } \\
\hline SIC Codes 8000-8999 & \multicolumn{9}{|c|}{ = Service industries: health, legal, educational, social, museums, engineering, accounting, management, etc. } \\
\hline TOTASSET & \multicolumn{9}{|c|}{$=$ Total assets (Compustat data item \#6). } \\
\hline NETSALES & \multicolumn{9}{|c|}{$=$ Net sales (Compustat data item \#12). } \\
\hline ALLOWDTA & \multicolumn{9}{|c|}{$=$ Deferred tax asset valuation allowance as a percentage of deferred tax assets. } \\
\hline FUTURE & \multicolumn{9}{|c|}{$=$ Deferred tax liabilities scaled by deferred tax assets. } \\
\hline EARN & $=$ The average oper & earnings & he most rec & years (the $y$ & write off $\mathrm{c}$ & turing charg & two previo & ) scaled by to & sets. \\
\hline МКТВООК & $=$ Market value of & on equity & y book valu & mon equity & & & & & \\
\hline DISTRESS & $=$ Indicator variable & $\mathrm{d}$ one if a & following co & are met: $(1$ & ws are neg & operating ir & negative, (3 & $\mathrm{m}$ has a net lo & \\
\hline STRATEGY & $=$ Federal income $\mathrm{t}$ & ense divi & operating $\mathrm{i}$ & & & & & & \\
\hline CONTIN & $=$ Indicator variable & $\mathrm{d}$ one if $\mathrm{t}$ & s a material & ncy and zer & & & & & \\
\hline PASTROA & $=$ Average return o & ts over th & three years & & & & & & \\
\hline Z-SCORE & $=$ Altman Z-score $\mathrm{b}$ & on Shumv & 7) updated & & & & & & \\
\hline
\end{tabular}




\section{Table 2}

\section{Descriptive statistics of deferred tax accounts}

\begin{tabular}{|c|c|c|c|c|c|}
\hline \multicolumn{6}{|c|}{ Panel A: Sample firms } \\
\hline Variable & Sample Size & 25th Percentile & Mean & Median & 75th Percentile \\
\hline \multicolumn{6}{|c|}{ Year -2 (Two Years prior to Announcement Year) } \\
\hline$\overline{\text { DTA }}$ & 308 & 0.028 & 0.210 & 0.062 & 0.170 \\
\hline VALALLOW & 308 & 0.000 & 0.162 & 0.011 & 0.134 \\
\hline DTL & 308 & 0.003 & 0.025 & 0.011 & 0.030 \\
\hline \multicolumn{6}{|c|}{ Year -1 (One Year prior to Announcement Year) } \\
\hline DTA & 427 & 0.033 & 0.249 & 0.076 & 0.200 \\
\hline VALALLOW & 427 & 0.000 & 0.205 & 0.016 & 0.164 \\
\hline DTL & 427 & 0.001 & 0.025 & 0.012 & 0.031 \\
\hline \multicolumn{6}{|c|}{ Year 0 (Announcement Year) } \\
\hline DTA & 444 & 0.079 & 0.429 & 0.158 & 0.387 \\
\hline VALALLOW & 444 & 0.004 & 0.354 & 0.091 & 0.355 \\
\hline DTL & 444 & 0.000 & 0.024 & 0.012 & 0.033 \\
\hline \multicolumn{6}{|c|}{ Panel B: Control firms } \\
\hline Variable & Sample Size & 25th Percentile & Mean & Median & 75th Percentile \\
\hline \multicolumn{6}{|c|}{ Year -2 (Two Years prior to Announcement Year) } \\
\hline$\overline{\text { DTA }}$ & 292 & 0.028 & 0.245 & 0.055 & 0.170 \\
\hline VALALLOW & 292 & 0.000 & 0.189 & 0.004 & 0.106 \\
\hline DTL & 292 & 0.002 & 0.029 & 0.012 & 0.035 \\
\hline \multicolumn{6}{|c|}{ Year -1 (One Year prior to Announcement Year) } \\
\hline$\overline{\text { DTA }}$ & 429 & 0.027 & 0.236 & 0.058 & 0.196 \\
\hline VALALLOW & 429 & 0.000 & 0.191 & 0.005 & 0.139 \\
\hline DTL & 429 & 0.001 & 0.026 & 0.010 & 0.032 \\
\hline \multicolumn{6}{|c|}{ Year 0 (Announcement Year) } \\
\hline$\overline{\text { DTA }}$ & 444 & 0.025 & 0.268 & 0.051 & 0.178 \\
\hline VALALLOW & 444 & 0.000 & 0.216 & 0.001 & 0.117 \\
\hline DTL & 444 & 0.001 & 0.023 & 0.010 & 0.030 \\
\hline$\overline{\mathrm{DTA}}$ & $=$ Deferred tax as & as a percentage of tc & & & \\
\hline $\begin{array}{l}\text { VALALLOW } \\
\text { DTL }\end{array}$ & $\begin{array}{l}=\text { Deferred tax va } \\
=\text { Deferred tax lia }\end{array}$ & $\begin{array}{l}\text { tion allowance as a p } \\
\text { tities as a percentage }\end{array}$ & $\begin{array}{l}\text { e of total a } \\
\text { ssets. }\end{array}$ & & \\
\hline
\end{tabular}


Table 3

\section{Univariate comparisons of changes in deferred tax accounts}

\begin{tabular}{|c|c|c|c|c|c|}
\hline \multicolumn{6}{|c|}{ Panel A: Sample firms } \\
\hline \multirow[b]{3}{*}{ Variable } & \multirow[b]{3}{*}{$\mathrm{N}$} & \multirow{3}{*}{$\begin{array}{c}\text { Mean } \\
\text { Change } \\
\end{array}$} & \multirow{3}{*}{$\begin{array}{l}\mathrm{H}_{\mathrm{o}}: \Delta=0 \\
t \text {-statistic }\end{array}$} & \multirow{3}{*}{$\begin{array}{l}\text { Median } \\
\text { Change }\end{array}$} & \multirow{3}{*}{$\begin{array}{c}\mathrm{H}_{0}: \Delta=0 \\
\text { Wilcoxon Signed-Rank } \\
Z \text {-statistic }\end{array}$} \\
\hline & & & & & \\
\hline & & & & & \\
\hline \multicolumn{6}{|c|}{ Changes from Year -2 and Year -1} \\
\hline$\overline{\Delta \mathrm{DTA}}$ & 308 & 0.055 & $3.36^{* * *}$ & 0.007 & $4.72^{* * *}$ \\
\hline$\triangle$ VALALLOW & 308 & 0.042 & $2.84^{* * *}$ & 0.000 & $2.47^{* *}$ \\
\hline$\triangle$ ALLOWDTA & 305 & 0.032 & $2.39 * *$ & 0.000 & $1.77 *$ \\
\hline \multicolumn{6}{|c|}{ Changes from Year -1 and Year 0} \\
\hline$\overline{\Delta \mathrm{DTA}}$ & 427 & 0.194 & $6.89 * * *$ & 0.067 & $21.10^{* * *}$ \\
\hline$\triangle$ VALALLOW & 427 & 0.158 & $6.99^{* * *}$ & 0.037 & $14.56^{* * *}$ \\
\hline$\triangle$ ALLOWDTA & 426 & 0.114 & $7.87 * * *$ & 0.000 & $7.48 * * *$ \\
\hline \multicolumn{6}{|c|}{ Panel B: Control firms } \\
\hline & & & & & $\mathrm{H}_{0}: \Delta=0$ \\
\hline & & Mean & $\mathrm{H}_{\mathrm{o}}: \Delta=0$ & Median & Wilcoxon Signed-Rank \\
\hline Variable & $\mathrm{N}$ & Change & $t$-statistic & Change & $z$-statistic \\
\hline \multicolumn{6}{|c|}{ Changes from Year -2 and Year -1} \\
\hline$\overline{\Delta \mathrm{DTA}}$ & 292 & 0.001 & 0.05 & 0.000 & 0.64 \\
\hline$\triangle$ VALALLOW & 292 & 0.003 & 0.20 & 0.000 & -0.02 \\
\hline$\underline{\Delta \text { ALLOWDTA }}$ & 289 & -0.014 & -1.45 & 0.000 & -1.13 \\
\hline \multicolumn{6}{|c|}{ Changes from Year -1 and Year 0} \\
\hline$\overline{\Delta \mathrm{DTA}}$ & 429 & 0.034 & 1.63 & -0.002 & -1.22 \\
\hline$\triangle$ VALALLOW & 429 & 0.024 & 1.54 & 0.000 & -1.43 \\
\hline$\triangle$ ALLOWDTA & 425 & -0.026 & $-2.59 * * *$ & 0.000 & $-2.51 * *$ \\
\hline \multicolumn{6}{|c|}{ * Indicates statistical significance at the 0.10 level (two-tailed test). } \\
\hline \multicolumn{6}{|c|}{ ** Indicates statistical significance at the 0.05 level (two-tailed test). } \\
\hline \\
\hline & \multirow{2}{*}{\multicolumn{5}{|c|}{$\begin{array}{l}=\text { Deferred tax assets as a percentage of total assets. } \\
=\text { Defered tax valuation allowance as a percentage of total assets. }\end{array}$}} \\
\hline VALALLOW & & & & & \\
\hline ALLOWDTA & \multicolumn{5}{|c|}{$=$ Deferred tax asset valuation allowance as a percentage of deferred tax assets. } \\
\hline
\end{tabular}




\section{Table 4}

\section{Deferred tax asset valuation allowance prediction regression}
ALLOWDTA $=a_{0}+a_{1}$ FUTURE $+a_{2}$ EARN $+a_{3}$ MKTBOOK $+a_{4}$ DISTRESS + $a_{5}$ STRATEGY $+a_{6}$ CONTIN $+a_{7}$ PASTROA + $a_{8} \mathrm{Z}-\mathrm{SCORE}+e$

\begin{tabular}{|c|c|c|}
\hline Variable & $\begin{array}{c}\text { Parameter } \\
\text { (Predicted Sign) }\end{array}$ & $\begin{array}{c}\text { Parameter Estimates } \\
\text { (T-statistics) }\end{array}$ \\
\hline Intercept & $\mathrm{a}_{0}$ & $\begin{array}{c}0.391 \\
(18.07)^{* * *}\end{array}$ \\
\hline FUTURE & $\begin{array}{l}a_{1} \\
(-)\end{array}$ & $\begin{array}{c}-0.048 \\
(-8.90)^{* * *}\end{array}$ \\
\hline EARN & $\begin{array}{l}a_{2} \\
(-)\end{array}$ & $\begin{array}{c}-0.496 \\
(-7.03)^{* * *}\end{array}$ \\
\hline MKTBOOK & $\begin{array}{l}a_{3} \\
(-)\end{array}$ & $\begin{array}{l}-0.001 \\
(-0.69)\end{array}$ \\
\hline DISTRESS & $\begin{array}{l}\mathrm{a}_{4} \\
(+)\end{array}$ & $\begin{array}{c}0.154 \\
(7.32)^{* * *}\end{array}$ \\
\hline STRATEGY & $\begin{array}{l}a_{5} \\
(-)\end{array}$ & $\begin{array}{c}-0.114 \\
(-5.35) * * *\end{array}$ \\
\hline CONTIN & $\begin{array}{l}\mathrm{a}_{6} \\
(+)\end{array}$ & $\begin{array}{l}-0.051 \\
(-1.14)\end{array}$ \\
\hline PASTROA & $\begin{array}{l}a_{7} \\
(-)\end{array}$ & $\begin{array}{c}-0.182 \\
(-6.27)^{* * *}\end{array}$ \\
\hline Z-SCORE & $\begin{array}{l}a_{8} \\
(-)\end{array}$ & $\begin{array}{c}-0.006 \\
(-1.82)^{*}\end{array}$ \\
\hline Adjusted-R ${ }^{2}$ & & 0.4508 \\
\hline \multicolumn{3}{|c|}{$\begin{array}{l}\text { Indicates statistical significance at the } 0.10 \text { level (one-tailed test if sign is predicted, otherwise two-tailed). } \\
\text { Indicates statistical significance at the } 0.05 \text { level (one-tailed test if sign is predicted, otherwise two-tailed). } \\
\text { Indicates statistical significance at the } 0.01 \text { level (one-tailed test if sign is predicted, otherwise two-tailed). }\end{array}$} \\
\hline $\begin{array}{l}\text { ALLOWDTA } \\
\text { FUTURE } \\
\text { EARN }\end{array}$ & $\begin{aligned}= & \text { Deferred tax asset valua } \\
= & \text { Deferred tax liabilities s } \\
= & \text { The average operating e } \\
& \text { the write off or restructu }\end{aligned}$ & $\begin{array}{l}\text { percentage of deferred tax assets } \\
\text { x assets } \\
\text { e most recent three years (the year o } \\
\text { two previous years) scaled by total asset: }\end{array}$ \\
\hline $\begin{array}{l}\text { MKTBOOK } \\
\text { DISTRESS }\end{array}$ & $\begin{aligned}= & \text { Market value of commo } \\
= & \text { Indicator variable coded } \\
& (1) \text { cash flows are negati } \\
& \text { a net loss. }\end{aligned}$ & $\begin{array}{l}\text { book value of common equit: } \\
\text { llowing conditions are me } \\
\text { come is negative, (3) the firm ha }\end{array}$ \\
\hline STRATEGY & $=$ Federal income tax expe & pperating incom $\epsilon$ \\
\hline CONTIN & $=$ Indicator variable coded & a material contingency and zero otherwis \\
\hline PASTROA & $=$ Average return on assets & hree years \\
\hline Z-SCORE & $=$ Altman Z-score based ol & updated coefficients \\
\hline
\end{tabular}




\section{Table 5}

\section{Univariate comparisons of changes in deferred tax accounts: Big bath versus small bath firms (year +1$)$}

\begin{tabular}{|c|c|c|c|c|}
\hline \multicolumn{5}{|c|}{ Panel A: Sample big bath firms--Top 33\% (ALLOWDTA - Predicted ALLOWDTA) } \\
\hline & & & & $\mathrm{H}_{\mathrm{o}}: \Delta=0$ \\
\hline & Mean & $\mathrm{H}_{\mathrm{o}}: \Delta=0$ & Median & Wilcoxon Signed-Rank \\
\hline Variable & Change & $t$-statistic & Change & $z$-statistic \\
\hline \multicolumn{5}{|c|}{ Changes from Year 0 and Year +1} \\
\hline$\overline{\Delta \mathrm{DTA}}$ & 0.092 & $2.95 * * *$ & 0.022 & $2.56^{* *}$ \\
\hline$\triangle$ VALALLOW & 0.087 & $2.76^{* * *}$ & 0.022 & $2.11 * *$ \\
\hline$\triangle$ ALLOWDTA & -0.055 & $-2.48 * *$ & 0.000 & -1.04 \\
\hline \multicolumn{5}{|c|}{ Panel B: Sample small bath firms--Bottom 33\% (ALLOWDTA - Predicted ALLOWDTA) } \\
\hline & & & & $\mathrm{H}_{\mathrm{o}}: \Delta=0$ \\
\hline & Mean & $\mathrm{H}_{\mathrm{o}}: \Delta=0$ & Median & Wilcoxon Signed-Rank \\
\hline Variable & Change & $t$-statistic & Change & $Z$-statistic \\
\hline \multicolumn{5}{|c|}{ Changes from Year 0 and Year +1} \\
\hline$\overline{\Delta \mathrm{DTA}}$ & -0.026 & -0.52 & 0.004 & 1.59 \\
\hline$\triangle$ VALALLOW & 0.024 & 0.70 & 0.000 & $2.87 * * *$ \\
\hline$\triangle$ ALLOWDTA & 0.107 & $4.45^{* * *}$ & 0.000 & $3.92 * * *$ \\
\hline \multicolumn{5}{|c|}{ Panel C: Univariate comparisons of big bath and small bath firms } \\
\hline Variable & $\begin{array}{l}\text { Difference } \\
\text { in Means }\end{array}$ & $t$-statistic & $\begin{array}{l}\text { Difference } \\
\text { in Medians } \\
\end{array}$ & $\begin{array}{c}\text { Wilcoxon Rank-Sum } \\
\text { Z-statistic } \\
\end{array}$ \\
\hline \multicolumn{5}{|c|}{ Changes from Year 0 and Year +1} \\
\hline$\overline{\Delta \mathrm{DTA}}$ & 0.118 & $1.94 * *$ & 0.018 & 1.46 \\
\hline$\triangle$ VALALLOW & 0.063 & 1.33 & 0.022 & 0.79 \\
\hline$\triangle$ ALLOWDTA & -0.162 & $-4.93 * * *$ & 0.000 & $-3.23 * * *$ \\
\hline \multicolumn{5}{|c|}{ * Indicates statistical significance at the 0.10 level (two-tailed test). } \\
\hline \multicolumn{5}{|c|}{ ** Indicates statistical significance at the 0.05 level (two-tailed test). } \\
\hline \multicolumn{5}{|c|}{$* * *$ Indicates statistical significance at the 0.01 level (two-tailed test). } \\
\hline $\begin{array}{l}\text { DTA } \\
\text { VALALLOW }\end{array}$ & $\begin{array}{l}\text { eferred tax ass } \\
\text { efered tax valu }\end{array}$ & $\begin{array}{l}\text { centage of tota } \\
\text { ance as a perc }\end{array}$ & 1 assets. & \\
\hline
\end{tabular}




\section{Table 6}

\section{Deferred Tax Valuation Allowance Reversals in Year +1 or Year +2}

\begin{tabular}{|c|c|c|c|c|}
\hline $\begin{array}{c}\text { Sample Firm } \\
\text { Category }\end{array}$ & $\begin{array}{c}\text { Total } \\
\text { Number of Firms } \\
\end{array}$ & $\begin{array}{c}\text { Number of Firms } \\
\text { NO } \\
\text { Reversal } \\
\end{array}$ & $\begin{array}{c}\text { Number of Firms } \\
\text { YES } \\
\text { Reversal } \\
\end{array}$ & $\begin{array}{c}\text { Percentage of } \\
\text { Reversals }\end{array}$ \\
\hline ZERO & 80 & 80 & 0 & $0.0 \%$ \\
\hline SMALL & 108 & 60 & 48 & $44.4 \%$ \\
\hline LARGE & 102 & 61 & 41 & $40.2 \%$ \\
\hline MAX & 68 & 45 & 23 & $33.8 \%$ \\
\hline Total & 358 & 246 & 112 & $31.3 \%$ \\
\hline
\end{tabular}

Note: The intial number of SMALL and LARGE firms was 128 and 129, respectively. The missing 47 firms did not have 10-K filings available on EDGAR for Year +1 or Year +2 .

\section{$\underline{\text { Sample Firm Categories }}$}

ZERO

= Sample firm established no valuation allowance in Year 0 (the bath year).

MAX

SMALL

$=$ In Year 0, the sample firm established the maximum amount of valuation allowance equal to either the deferred tax asset in Year 0 or the net deferred tax asset (deferred tax asset minus deferred tax liability). In either case, the valuation allowance is of an amount large enough to result in a net reported deferred tax asset of zero.

= Of the sample firms that are not ZERO and not MAX, the firms with valuation allowance prediction errors in the lower half of the distribution indicating that the valuation allowance is smaller than predicted.

LARGE

$=$ Of the Sample firms that are not zero and not MAX, the firms with valuation allowance prediction errors in the upper half of the distribution indicating that the valuation allowance is larger than predicted.

\section{$\underline{\text { Reveral Categories }}$}

NO

$=$ The valuation allowance was equal to or greater than the Year 0 balance in both Year +1 and Year +2 . 
Table 7

Operating Performance in Year +1 Depending on the Size of the Valuation Allowance in Year 0 and whether there was a Subsequent Reversal

\begin{tabular}{|c|c|c|c|c|}
\hline \multicolumn{5}{|c|}{ Panel A: Operating Performance in Year +1 by Year 0 Allowance Group } \\
\hline \multirow{4}{*}{$\begin{array}{l}\text { Sample Firm } \\
\text { Category }\end{array}$} & \multirow{2}{*}{\multicolumn{2}{|c|}{$\begin{array}{c}\text { Year }+1 \\
\text { Operating Income / Assets }\end{array}$}} & \multirow{2}{*}{\multicolumn{2}{|c|}{$\begin{array}{c}\text { Year +1 } \\
\text { EBITDA / Assets }\end{array}$}} \\
\hline & & & & \\
\hline & Mean & & Mean & \\
\hline & t-statistic $\neq 0$ & Median & t-statistic $\neq 0$ & Median \\
\hline$\overline{\text { ZERO }}$ & $\begin{array}{c}5.9 \% \\
t=+4.52\end{array}$ & $7.7 \%$ & $\begin{array}{c}11.6 \% \\
t=+9.19\end{array}$ & $13.7 \%$ \\
\hline SMALL & $\begin{array}{c}-4.2 \% \\
t=-1.66\end{array}$ & $2.8 \%$ & $\begin{array}{c}2.2 \% \\
\mathrm{t}=+0.91\end{array}$ & $9.3 \%$ \\
\hline LARGE & $\begin{array}{c}-11.1 \% \\
t=-4.02\end{array}$ & $-4.2 \%$ & $\begin{array}{c}-3.6 \% \\
t=-1.39\end{array}$ & $3.1 \%$ \\
\hline MAX & $\begin{array}{c}-59.8 \% \\
t=-3.63\end{array}$ & $-11.5 \%$ & $\begin{array}{c}-42.9 \% \\
t=-2.72\end{array}$ & $-2.5 \%$ \\
\hline \multicolumn{5}{|c|}{ Panel B: Operating Performance in Year +1 by whether there was a subsequent reversal } \\
\hline $\begin{array}{c}\text { Sample Firm } \\
\text { Category }\end{array}$ & $\begin{array}{r}\text { Year }+1 \text { Opera } \\
\text { NO } \\
\text { Mean } \\
\text { t-statistic } \neq 0 \\
\end{array}$ & me / Assets & $\begin{array}{r}\text { Year +1 Ope } \\
\text { Mean } \\
\text { t-statistic } \neq 0 \\
\end{array}$ & me / Assets \\
\hline ZERO & $\begin{array}{c}5.4 \% \\
t=+4.09\end{array}$ & $7.6 \%$ & $\mathrm{n} / \mathrm{a}$ & $\mathrm{n} / \mathrm{a}$ \\
\hline SMALL & $\begin{array}{c}-13.3 \% \\
t=-3.14\end{array}$ & $-2.6 \%$ & $\begin{array}{c}6.0 \% \\
t=+3.86\end{array}$ & $7.9 \%$ \\
\hline LARGE & $\begin{array}{c}-22.0 \% \\
t=-5.64\end{array}$ & $-15.2 \%$ & $\begin{array}{c}4.9 \% \\
t=+2.24\end{array}$ & $5.6 \%$ \\
\hline MAX & $\begin{array}{c}-77.4 \% \\
t=-3.05\end{array}$ & $-25.1 \%$ & $\begin{array}{c}-1.8 \% \\
t=-0.35\end{array}$ & $4.2 \%$ \\
\hline \multicolumn{5}{|c|}{ Note: The reported t-statistics are for a parametric test of the difference of the reported percentages from zero. } \\
\hline \multicolumn{5}{|c|}{$\underline{\text { Sample Firm Categories }}$} \\
\hline ZERO & \multicolumn{4}{|c|}{$=$ Sample firm established no valuation allowance in Year 0 (the bath year). } \\
\hline MAX & \multicolumn{4}{|c|}{$\begin{array}{l}\text { = In Year 0, the sample firm established the maximum amount of valuation allowance } \\
\text { equal to either the deferred tax asset in Year } 0 \text { or the net deferred tax asset (deferred tax } \\
\text { asset minus deferred tax liability). In either case, the valuation allowance is of an } \\
\text { amount large enough to result in a net reported deferred tax asset of zero. }\end{array}$} \\
\hline SMALL & \multicolumn{4}{|c|}{$\begin{array}{l}=\text { Of the sample firms that are not ZERO and not MAX, the firms with valuation } \\
\text { allowance prediction errors in the lower half of the distribution indicating that the } \\
\text { valuation allowance is smaller than predicted. }\end{array}$} \\
\hline LARGE & \multicolumn{4}{|c|}{$\begin{array}{l}=\text { Of the Sample firms that are not zero and not MAX, the firms with valuati } \\
\text { allowance prediction errors in the upper half of the distribution indicating that the } \\
\text { valuation allowance is larger than predicted. }\end{array}$} \\
\hline \multicolumn{5}{|l|}{$\underline{\text { Reveral Categories }}$} \\
\hline NO & \multicolumn{4}{|c|}{$=$ The valuation allowance was equal to or greater than the Year 0 balance in both Year +1 and Year +2 . } \\
\hline YES & $=$ The valuation allow & ess than the $\mathrm{Y}$ & ance in either Yea & \\
\hline
\end{tabular}


Table 8

Sample Firms for Which a Subsequent Change in Valuation Allowance Converted a Loss into a Profit

\begin{tabular}{|c|c|c|c|c|c|}
\hline \multirow{2}{*}{\multicolumn{6}{|c|}{ Sample Firm }} \\
\hline & & & & & \\
\hline Category & \multicolumn{2}{|r|}{ Year +1 } & \multicolumn{2}{|r|}{ Year +2} & \\
\hline OPPORTUNITY & \multicolumn{2}{|r|}{89} & \multicolumn{3}{|c|}{79} \\
\hline MANAGE & \multicolumn{2}{|r|}{6} & \multicolumn{3}{|c|}{6} \\
\hline Percentage & \multicolumn{2}{|r|}{$6.7 \%$} & \multicolumn{3}{|c|}{$7.6 \%$} \\
\hline \multicolumn{6}{|c|}{ Panel B: List of sample firms that did change a loss to a profit (numbers in millions) } \\
\hline $\begin{array}{l}\text { Company } \\
\text { Name }\end{array}$ & Year 0 & $\begin{array}{l}\text { Pre-Valuation Earnings } \\
\text { in MANAGE } \\
\text { Year }\end{array}$ & $\begin{array}{l}\text { Valuation } \\
\text { Beginning } \\
\text { Balance }\end{array}$ & $\begin{array}{l}\text { Reduction in } \\
\text { Valuation }\end{array}$ & $\begin{array}{l}\text { Reported } \\
\text { Earnings }\end{array}$ \\
\hline Firm A & 1997 & $(0.923)$ & 2.362 & 1.663 & 0.740 \\
\hline Firm B & 1998 & (4.177) & 15.067 & 15.067 & 10.890 \\
\hline Firm C & 1998 & $(11.329)$ & 45.339 & 45.339 & 34.010 \\
\hline Firm D & 1996 & $(0.170)$ & 1.750 & 0.250 & 0.080 \\
\hline Firm E & 1996 & $(0.408)$ & 9.943 & 0.778 & 0.370 \\
\hline Firm F & 1998 & $(0.052)$ & 10.966 & 0.132 & 0.080 \\
\hline Firm G & 1996 & $(2.830)$ & 16.050 & 4.400 & 1.570 \\
\hline Firm H & 1998 & $(0.212)$ & 1.632 & 0.232 & 0.020 \\
\hline Firm I & 1998 & $(4.660)$ & 43.200 & 6.500 & 1.840 \\
\hline Firm J & 1996 & $(4.750)$ & 66.970 & 8.160 & 3.410 \\
\hline Firm K & 1998 & $(0.723)$ & 35.463 & 1.063 & 0.340 \\
\hline Firm L & 1997 & $(0.235)$ & 21.645 & 0.475 & 0.240 \\
\hline OPPORTUNITY & \multicolumn{5}{|c|}{$\begin{array}{l}=\text { Sample firms for which the pre-valuation allowance earnings is negative and } \\
\text { the beginning balance in the valuation allowance is large enough so that a reduction in } \\
\text { the allowance to zero could change the negative earnings to positive earnings. }\end{array}$} \\
\hline MANAGE & \multicolumn{5}{|c|}{$\begin{array}{l}=\text { Sample firms that did use the valuation allowance to convert negative earnings to } \\
\text { positive earnings. }\end{array}$} \\
\hline $\begin{array}{l}\text { Pre-Valuation } \\
\text { Earnings }\end{array}$ & \multicolumn{5}{|c|}{$\begin{array}{l}\text { = What the sample firm's net income before extraordinary items would have been if there } \\
\text { had been no change in the deferred tax valuation allowance during the year. A decrease } \\
\text { in the valuation allowance increases net income (and therefore needs to be taken out to } \\
\text { get back to pre-allowance net income); an increase in the valuation allowance } \\
\text { decreases net income (and so needs to be added back). The computations are as follows. } \\
\text { Pre-valuation net income = Net income + Ending Allowance - Beginning Allowance }\end{array}$} \\
\hline
\end{tabular}

